\title{
Social Structure of the Early Medieval Türks in the Altai-Sayan Region: Archaeological Perspectives*
}

\author{
Nikolai N. Seregin \\ Institute of Mongolian, Buddhist, and Tibetan Studies, \\ Siberian Branch of the Russian Academy of Sciences, \\ Altai State University
}

\begin{abstract}
The article concerns various aspects of the social interpretation of funeral complexes of the early medieval Türks (dating to the second half of the first millennium AD). The results of the analysis of sites excavated in the Altai, Tuva and Minusinsk basin are presented here. The available material, along with theoretical and practical experience of Russian and foreign scientists allowed for the development of an original social research program. We also define the features of gender and age differentiation of the early medieval Turkic society and consider opportunities of modeling the vertical structure of society. In the article we also distinguish the groups of burials showing the heterogeneity of nomads in the Altai-Sayan region in the second half of the first millennium AD. The results obtained through social analyses of funeral complexes are combined with data from written sources, in particular with the Chinese chronicles and Turks runic texts.
\end{abstract}

\section{INTRODUCTION}

For a long time the study of social history of the Eurasian nomads has remained an independent field of research. The relevance and significance of scholarly works on the topic have been defined by a whole range of factors, not least the specifics of the nomadic societies' development (which differed considerably from much better investigated state entities of the settled agriculturalists), as well as the impact the nomads produced on the fortunes of many other peoples. During various historical periods, nomads created peculiar social systems, most of them short-lived but leaving noticeable imprints on the humankind's history.

Social Evolution \& History, Vol. 18 No. 2, September 2019 133-147

(C) 2019 'Uchitel' Publishing House

DOI: $10.30884 / \mathrm{seh} / 2019.02 .07$ 
The early medieval Türks of the Altai-Sayan region and Central Asia were one of the most colorful nomadic communities. The founders of the largest nomadic empire (the Great Turkic Khaganate, 551/552-630 AD), stretching far beyond the above-specified area, they exerted a strong influence on historical, cultural and ethnogenetic processes in vast territories. After the collapse of the Khaganate and years of dependence on China (630-682 AD), the nomads managed to restore their empire, which existed until $744 \mathrm{AD}$ when it was incorporated into political coalitions of the Uyghurs and the Qïriiz. Despite their relatively short history, the early medieval Türks created a vivid culture and ideology, as well as a complex social system, which became a model for many of the nomadic tribes of the Central Asian region.

This paper aims at studying the social history of the early medieval Türks of the Altai-Sayan region. This is not an entirely new topic of research. There is a rich historiography on various aspects of nomadic society's development in the second half of the first millennium AD (Bernshtam 1946: 87-147; Kychanov 1997: 94-120; Klyashtorny and Savinov 2005: 149-158; etc.). However, until the present all generalizing works along those lines have been based on the analysis of written sources such as runic texts and Chinese dynastical chronicles. Undoubtedly, further study of these documents will be fruitful. However, one should admit that the research capabilities for interpreting these materials are seriously limited. Thus, in this paper, archaeological monuments act as the basis for the reconstruction of the social history of the early medieval Türks. The most informative of them are the burial complexes.

\section{SOURCES AND RESEARCH PROGRAM}

Despite a long history of study and interpretation of archaeological monuments of the Altai-Sayan region and Central Asia, there is still no consensus on which complexes can be exactly correlated with the early medieval Türks. Rather than focusing on contemporary scholarly views, we would emphasize that in our view the most reasonable and justified is the correlation of this particular ethnopolitical entity with the body of monuments belonging to the Turks archaeological culture and represented by inhumation burials accompanied by a horse, 'commemorative' stone enclosures, sculptures, elaborate 'elite' memorial complexes, and so on. Burials of the early medieval Türks (the second half of the fifth - ninth centuries AD) are excavated mostly in the territory of the Altai, Tuva, and Minusinsk basins. Most of them are located in the Altai-Sayan region. One refers to far less numerous burials, explored in Mongolia, Kazakhstan and Central Asia for clarification of individual aspects of nomadic history.

The burial complexes of the early medieval Altai-Sayan Türks display a number of features, which, on the one hand, impede their social 
interpretation, while on the other hand, also define the research methods and approaches. The most significant of these factors are the relatively small number of burials (a bit more than 300); the large number of plundered complexes (over 30 per cent of the total number of monuments); the uneven distribution of the number of burials across different chronological periods of cultural development; paucity of anthropological definitions; and the considerable degree of evening out of nomadic rite. These circumstances make it necessary to reconsider traditional approaches to social reconstructions based on the materials from burial monuments. In particular, due to a limited number of objects, the statistical analysis methods are much less significant because, as is known, small samplings are unrepresentative in such cases (Kradin, Danilov, and Konovalov 2004: 31).

In view of the findings of the Russian and foreign scholars and taking into account the peculiarities of available data, one may develop a research program for the reconstruction of the societal structure of the early medieval Altai-Sayan Türks. The first stage of the program implies a comprehensive systematization and analysis of archaeological materials from excavated burial complexes. The second stage seeks to consider the horizontal stratification of the early medieval Turkic society, mostly reflected in gender and age differentiation of burial rites. This research stage studies the parameters of burial structures, rituals, and sets of accompanying objects, characteristic of male, female and children burials, as well as burials of persons from certain age groups. The expansion of the source base by determining the gender of deceased people through archaeological objects lacking anthropological characteristics is an important point. The identification of attributes whose variability is associated with the gender and age of the buried individuals will allow for specification of the socially induced elements of a rite. This research activity will be carried out in the third stage of the study. The fourth stage represents an interpretation of results obtained from the analysis of archaeological materials. Modeling of a hypothetical structure of the society of the early medieval Türks of the Altai-Sayan region through the identification and characterization of burial groups is the primary objective. Further research stages allow for correlation of the results of the analysis of the burial complexes with other sources. In this particular case, the written resources obtain the highest significance since they allow us to considerably expand and complement the ideas about various aspects of Turkic societal organization as well as the evolution of the nomadic social system throughout the second half of the first millennium AD.

In order to carry out the social analysis of the materials we selected a peculiar sample consisting of 204 burials, excavated in the Altai region (95 objects), Tuva (48 objects) and Minusinsk Basin (61 objects). The opportunity for determining the gender of the deceased, a necessary condition for the comprehensive interpretation of burials, is the major factor 
in the selection of monuments from the total number of excavated tombs (over 350 ). We singled out 40 female, 133 male and 31 children and adolescents burials (Seregin 2013a: 49-50). The analysis of this burial sampling/sample formed the basis for the studies of gender and age differentiation of the early medieval Turkic society of the Altai-Sayan region, as well as for the investigation of 'social markers' of the rite and modeling of the social structure of the nomads.

\section{GENDER AND AGE DIFFERENTIATION OF SOCIETY}

It is commonly known that societies have gender stereotypes which are socially differentiated ideas about personal qualities and behavioral models of men and women. These stereotypes are usually quite resilient but they may change under certain conditions. Gender stereotypes are one of the formative factors for the social relationships system. Therefore, their study is highly significant for the reconstruction of the way certain societies used to be organized (Ryabova 2003: 132). The previous research, conducted mostly by the Western scholars, has shown the informational value of materials obtained through the excavation of archaeological monuments for the study of social roles of men and women (Berseneva 2010b: 73).

The analysis of the burial complexes of the early medieval AltaiSayan Türks allowed us to single out two principal groups of indicators. The first group includes attributes whose variability is not directly associated with gender differentiation of the nomadic rites (types of surface and chamber structures, positioning of the body). The second group of attributes includes characteristics peculiar to male and female burials (the parameters of burial structures, the number of horses, the scope and quantity of accompanying items).

The clearest indicator of gender differentiation in the materials from the burial complexes of the early medieval Türks of the Altai-Sayan region is the scope of the assemblage of accompanying objects/grave goods. The study of the distribution tendencies of various categories of burial items revealed four distinct groups of items: 1) items characteristic of male graves only (arms, belts decorated with plates, silver vessels, Chinese coins, cauldrons, adzes, touchstones, and bent awls|); 2) items which do not appear to indicate gender, encountered in both male and female graves (fragments of silk clothes, knives, horse harnesses, ceramic vessels, lashes); 3) finds predominantly characteristic of female graves, rarely encountered in male burials (earrings, various costume decorations, combs, horse harness decorations); and 4) items found only in female graves (metallic mirrors, pincushions, and spindle whorls).

In general, notwithstanding certain particular cases (Seregin 2012: 63-64), the materials found at excavation sites on the burial complexes 
of the early medieval Türks of the Altai-Sayan region testify to the presence of rigid gender stereotypes manifested in the funeral rites of the nomads and demonstrating a division of social roles and functions of men and women typical for nomadic societies.

The peculiar character of the indicators of funeral rites was also defined by the age differentiation in the society of the early medieval Türks of the Altai-Sayan region. Taking into account the limited number of burials with anthropological determinations, it appears that division of the analyzed sampling into a large number of groups according to the traditional division commonly accepted in anthropology (Alekseev and Debets 1964: 39) is unproductive. Singling out only a few principal age groups is more appropriate in such a situation (Berseneva 2011: 51). This approach, aimed mostly at the identification of common tendencies and patterns of age differentiation in a society at the same time does not preclude the consideration of particular nuances in a case, if such observations are provided with all required materials.

Age differentiation of the society of the early medieval Türks of the Altai-Sayan region can be considered within the frameworks of four main groups: 1) children (under the age of 14 and, with segregation of an intermediate 'adolescent' group - under 18 years of age); 2) youth (18-25 years old); 3) adults (25-45 years old); and 4) senior adults (older than 45-50).

The small number of children's burials is a distinguishing feature of the obtained materials, especially since there is no need for a specialized report from an anthropologist to identify the graves of this age group. Nevertheless, this situation is not unique. A low percentage of children burials was noted in the course of study of a whole range of ancient and medieval societies (Berseneva 2010a: 108). This is especially typical for the highly mobile nomadic communities (Balabanova 2009: 83-84). However, judging by the available materials, the main explanation for this fact lies in the specificity of funeral rites of the early medieval Türks. It is likely that children burials did not always include the construction of a 'standard' burial complex, which significantly complicates their identification.

There are several groups of children burials: 1) those whose construction consisted of a barrow with a single grave underneath; 2) burials placed under a barrow alongside other burials; 3 ) children burials inside adult burials; 4) rock burials; and 5) burials in the space between barrows.

Despite the variability within recorded traditions, the children burial rite standard demonstrates a high degree of similarity of the principal components with traditions characteristic of the adult population of the society of the early medieval Altai-Sayan Türks. However, one can trace some distinguishing features. The most significant of them were the 'reduced' pa- 
rameters of burial structures, the absence of horse or their substitution with sheep, as well as the quality and quantity of accompanying objects.

The relative scarcity of reliable dates and a fragmentary nature of the archaeological materials make it impossible to determine clear stages in the socialization in the early modern Altai-Sayan Türkic society. At the same time, one should note that adolescent burials (from 14-15 years of age) can be more easily identified. They are distinguished by a higher frequency of horse burials and the accompanying items that cannot be found in the children's burials, which in certain cases demonstrate gender identity of the deceased. However, a number of objects associated with burials of the age group in question have attributes that are more similar to those found in children's burials.

The number of young people's burials in the sample is relatively small. This is probably due to a low mortality rate in that particular age group. Evidently, persons in this age group were very active and, judging from available data, could occupy high positions in the society of the early medieval Türks. This appears to be especially true when it comes to the status of young warriors (Mogilnikov 1997: 198-202; Kubarev 2005: 372-373). Rare burials of women belonging to this age group generally confirm the patterns described above (Mogilnikov 1990: 142-144). On the other hand, one should point that far from all young men were high ranked in the social hierarchy. A number of burials of men aged from 16 to 20 display a high degree of similarity with the adolescent burials (Gryaznov and Khudyakov 1979: 152-153; Poselyanin, Kirginekov, and Tarakanov 1999: 95; etc.).

A large number of objects with available anthropological definition are associated with the adult age group. The excavated materials from the burial complexes of the early medieval Türks indicate a higher mortality rate in this age group, especially among individuals older than 35-40. On the other hand, this life stage is also associated with the highest level of physical activity. In traditional societies this to a significant degree determines the social status. Actually, the burials associated through a set of attributes with the elite of the early medieval nomadic society were most often created for the deceased mature adults (Seregin 2013b: 76-78). At the same time, it is necessary to point out that just within this age group we observe the highest differentiation of social status. There is a number of burials lacking in their materials any markers that the deceased belonged to the highest social strata. Besides, some objects are clearly associated with people belonging to the lower social strata. In this particular case, it is highly probable that the difference in social status was not connected with the age of the deceased, but was determined by some other factors.

A representative series of burials within the analyzed sample demonstrates the social position of elderly people in the society of the early medi- 
eval Türks of the Altai-Sayan region. Judging by documented markers, the men over the age of 45 often had a high social status among the nomads. The materials under analysis include a group of burials of elderly persons belonging to various levels of nomadic elites (Evtyukhova and Kiselev 1941: 113-114; Trifonov 2000: 143-147; Kubarev 2005: 368). On the other hand, no less obvious is the reduced number of arms, including rare and 'prestigious' items (mostly bladed weapons), found even in 'rich' burials of elderly men over the age of 45 . Findings of the above items in such tombs are merely isolated cases (Gavrilova 1965: 67-68; Nesterov and Khudyakov 1979: 88-90). Perhaps, this situation indicates a general tendency towards preservation of high social status by elderly men and also their decreasing status in the military hierarchy due to objective circumstances.

Elderly women also enjoyed a high status in the studied society. It is important to emphasize that in this case no decrease in status connected with advanced age was observed. The excavated materials from the burial monuments show that the role of elderly women in nomadic society did not diminish but, on the contrary, grew with age (Savinov 1994: 104-124; Kubarev 2005: 369; etc.). Obviously, the inevitable decrease in physical activity and limited participation in labor were balanced by accumulated experience and authority.

\section{VERTICAL STRATIFICATION OF SOCIETY}

Modeling of the structure and organization of ancient and medieval communities is one possible application of the study of social history through materials from burial monuments. Theoretical and practical aspects of such studies are well-represented in historiography (Tishkin and Dashkovsky 2003: 106-108), so there is no need to discuss them in this paper. We will only emphasize the most important points connected with the realization of the aforementioned approach to the material available. A multi-staged object analysis involving sequential correlation of all rite indicators, foremost those defined as socially significant, formed the basis for the identification of social-typological models as represented by the groups of burials (Seregin 2013a: 76-97). Each of the identified models is characterized by a certain number of markers. Male, female and children burials were analyzed separately due to the observed gender and age differentiation in the rites of the early medieval Türks of the Altai-Sayan region. A high degree of marker coalescence was revealed for the objects arranged into the specified social-typological groups. Variability of the markers is generally insignificant. Below, we will present the most illustrative attributes characteristic of each of the designated groups.

The most complete picture of differentiation of the early medieval Türkic society of the Altai-Sayan region can be restored from the materials from male burials. The main marker distinguishing the burial models is the 
ratio between the accompanying items included in the 'authority complex' (rare arms, lashes, cauldrons, etc.) and in the 'wealth complex' (toreutics, imported goods). Other rite characteristics, such as the number of horses and the dimensions of surface and chamber structures were less important. In total nine social-typological models were singled out. Model I (three objects $-2.25 \%$ ) includes burials marked by the most numerous and diverse distribution of the accompanying objects including items from both the 'authority complex' and 'wealth complex'. The deceased person was accompanied by two to four horses. The outer dimensions of the barrow and chamber were also indicative. Model II burials (seven objects $5.25 \%$ ) also included objects from the 'authority complex' and 'wealth complex', but with fewer categories of findings and few items made from precious metals. There were one or two horses in these tombs. As for the dimensions of surface and chamber structures, these burials were distinguishable only as parts of some necropolises. Model III burials (eight objects $-6 \%$ ) are characterized by a minimal set of weapons (bow and arrows or even only one of these projectile weapons). Yet, at the same time, there was a rather demonstrative number of toreutics, including those decorated with precious metals. Model IV (five objects $-3.75 \%$ ) also includes burials with a minimal set of weapons or even absence thereof, combined with toreutic items, whose composition is visibly poorer than the finds from excavation sites of the third group. In three tombs there was no accompanying horse while in the rest there was only one animal. Burials assigned to Model V (12 objects - 9\%) are comparable with Model II burials, albeit with a more modest set of toreutics. Model VI (seven objects $-5.25 \%$ ) includes burials characterized by a diverse makeup of armaments, which almost in all cases included bladed close combat weapons and, much less often, a spear and defensive armor, combined with the total absence of toreutics and other items from the 'wealth complex'. A standard marker of Model VII burials ( 32 objects $-24 \%$ ) is a minimal set of weapons and a plate-decorated belt mostly made from bronze. Some tombs in this category contained a few horse harness decorations. Model VIII ( 51 objects $-38.3 \%$ ) includes burials characterized by the absence of items included in either the 'authority complex' or the 'wealth complex'. Such burials included a minimal set of weapons. Of all toreutic items only four tombs contained bronze earrings. Model IX (eight objects $-6 \%$ ) includes burials characterized by a total lack of weapons and toreutics. The most frequently found items in such tombs are tools of trade (knife, adz) as well as horse trappings.

Female burials display a smaller degree of differentiation. The analysis of objects from these burials allowed us to distinguish four models. The quality and quantity of toreutics items was the main social group marker. Other attributes were less important. Model I burials ( 8 objects $20 \%$ ) were characterized by the most diverse set of accompanying ob- 
jects including no less than two or three 'highly prestigious' items, such as metallic mirrors as well as horse harness decorations and earrings, in most cases manufactured with the use of precious metals. Model II burials $(12$ objects $-30 \%)$ are distinguished by the rarity of toreutics items made from precious metals, as well as a smaller number of socially significant finds in one tomb (no more than two). Model III burials (eight objects $-20 \%$ ) are characterized by the absence of precious metals items. In all these burials, there was one, less often, two categories of bronze toreutics items. A standard marker of Model IV burials (12 objects $30 \%$ ) was the total absence of toreutics. The most widespread archaeological finds were knives and horse trappings.

The analysis of scarce children burials allowed us to distinguish three social models. Model I (three objects $-9.7 \%$ ) includes burials with 'prestigious' bronze toreutics among the accompanying items. Burials of Model II (six objects - 19.3\%) are characterized by the rare presence of items frequently encountered in adult burials (arrowheads, earrings, etc.). In two cases a horse burial was found in a child's tomb. Model III burial ( $22 \mathrm{ob}-$ jects $-71 \%$ ) is characterized by a minimal amount of accompanying items or their total absence.

These models demonstrate a vertical structure in the early medieval Türkic society of the Altai-Sayan region. Without going into a detailed interpretation of all mentioned groups of burials, we will draw attention to the complexity of the nomadic society, particularly to the heterogeneity of the nomadic elite: the presence of a professional warrior group and the existence of highly positioned persons apart from the military. The heterogeneity of the nomadic society is also confirmed by the archaeological materials from burials identified as belonging to the vassal population. It appears that the peculiarities of the latter group's status may be reflected in the excavated materials from individual burials with no accompanying items, not included into the analyzed sample due to the lack of necessary data.

\section{DISCUSSION}

Many characteristics of the social order among early medieval nomads identified through the materials from the burial complexes in the AltaiSayan region are confirmed by written sources, such as the Chinese dynastical chronicles and Turkic runic texts.

Accounts of the early medieval authors can complement the picture of gender differentiation in the Turkic society. On the one hand, the written sources reflect traditional behavioral models for both genders. Warfare was the principal male pastime. A thorough description of constant military campaigns is provided by runic monuments. Aside from that, men tended cattle and were engaged in hunting and crafts mostly connected with the manufacture of metal products. Women were responsible 
for all other household duties as well as upbringing of children. At the same time, some accounts from early medieval authors suggest that women occupied a high social position in Turkic societies, and had access to a much broader range of functions.

Written sources repeatedly pointed to the respect and veneration of the qatun and kaghan's mother (Liu Mau-tsai 2002: 70). The inscription in honor of Tonyukuk describes a situation in which the kaghan, while on a military campaign, left the army to return home to perform 'funeral ceremonies' when his spouse died (Malov 1959: 68). In another runic script monument, the 'qatun-mother' was named the noblest of women in the horde saved by Kül Tegin from the enemy (Ibid.: 42). There is a mention that the wife of the Türkic ruler taking part in 'military undertakings' (Liu Mau-tsai 2002: 40). It appears that the qatun maintained her power after the death of her husband while her son, the heir apparent to kaghan's throne, was underage (Bichurin 1950: 277). The dynastical chronicles, due to perfectly understandable reasons, repeatedly highlight the role of the Chinese 'princesses' married to Türkic rulers in the political processes (Ibid.: 240-241, 247; Liu Mau-tsai 2002: 64; etc.).

The analysis of written sources demonstrates how diverse the social status of women was in nomadic society (Malov 1959: 42; Liu Mau-tsai 2002: 70). Of special interest are the mentions of women performing certain cultic functions in the dynastic chronicles (Liu Mau-tsai 2002: 23, 97, 99).

The information from the written sources considerably complements scattered observations on the age stratification of the early medieval Turkic society based by the materials from burial complexes. Judging from the data from the Türkic runic texts, the coming-of-age of children and their inclusion into economic activities, including the raising of boys into the ranks of adult warriors, occurred quite early. It is known that by the age of sixteen Kül Tegin had already 'earned a warrior reputation' and succeeded in restoring the Türks state (Tugusheva 2008: 44). At the age of seventeen Bilgä Qayan successfully led a military campaign against the Tanguts (Ibid.: 58).

However, these written sources contain practically no information about preadolescent children. A rare exception is a well-known legend about the origin of the Türks where the main character is a boy who rescued from captivity and founded the Ashina clan (Bichurin 1950: 220). It demonstrates that before reaching a certain age, children were not regarded as independent members of nomadic society and, perhaps, getting this status required a performance of certain ritual actions, many variants of which are known from ethnographic data.

Observations about the high status of the elderly have also been confirmed. The Chinese chronicles and Türkic texts repeatedly display an expressly respectful attitude towards mothers (Liu Mau-tsai 2002: 70; 
Tugusheva 2008: 42, 44). Apparently, this reflected the common treatment of elderly women. There are mentions of the considerable role of women in the management of various societal structures and the high authority of the elders (Bichurin 1950: 221, 239, 243, 255, 271; Tugusheva 2008: 78). The inscription in the monument in honor of the wellknown commander Tonyukuk, the following reference to elderly status is provided, 'I myself grew old and became venerable' (Tugusheva 2008: 86).

The written sources are far less informative when the vertical stratification of the early medieval Turkic society is concerned. A large portion of information on this matter is associated with the characteristics of the nomadic elite. There are also repeated mentions of subordinate segments of population (Bernshtam 1946: 110-126; Klyashtorny and Savinov 2005: 156-157; Tishin 2014: 93-107). Yet the information that would allow elaborating the peculiarities of differentiation among the rank-andfile nomads comprising the bulk of the early medieval Turkic society is almost entirely missing. Considering the available sparse knowledge and taking into account the general tendencies of the social history of the nomads one may assume that the stratification was mainly connected with the military-administrative system of management in Türkic khaganates.

\section{CONCLUSION}

The materials from the burial complexes of the early medieval Türks of the Altai-Sayan region reflect the high degree of heterogeneity of the nomadic society. One of its constituents was social differentiation. The analysis of the excavated monuments became the basis for the reconstruction of the gender and age structure of the society, as well as for identification of the principal social groups demonstrating the vertical structure of nomadic communities.

Based on the available evidence, one may argue that in Turkic society there existed stable gender stereotypes which were largely caused by a gender division of labor. Data from written sources confirm our observations, but also suggest that women could have played a more active part in various social and political spheres. It should be noted that gender stereotypes were also defined in the materials found in children burials, which constitute evidence for the early inclusion of persons from this age group into the system of social relations.

A limited number of anthropological definitions hamper a thorough tracing of the stages of socialization in early medieval Turks society. At the same time, it seems certain that a person's status depended heavily on his or her age group. Men and women aged from 25 to 45 had the highest significance in the nomadic society. It was at this stage of life that physical activity peaked, which often determined a higher social status in traditional societies. A majority of burials identified by a number of 
markers as belonging to the elite of the early Turkic societies had been constructed for the deceased of mature age. Not infrequently, elderly persons preserved their high social standing, which was explained by the social value of their accumulated experience, knowledge, or authority. However, archaeological materials also demonstrate a decrease in the role of elderly men in the military hierarchy due to reduced physical capabilities.

One of the characteristics of funeral rites of the early medieval Türks of the Altai-Sayan region and Central Asia is the high degree of their commonality. This indirect testimony to the consolidation level of the society seriously complicates social reconstructions by leveling down the significance of many ritual elements that had been considered as absolute markers of the earthly social status of the deceased in the study of earlier nomadic entities. The statistical and contextual analysis of excavated archaeological materials from the early medieval Turkic burials allowed us to conclude that their structures together with the number of horses in the chamber were relative indicators of social status of the deceased. The main criterion for the identification of the earthly social status of the deceased was the accompanying items found in the tomb. Further correlation of the identified socially significant elements of ritual practice, mostly 'social markers', formed the foundation for the division of burial groups reflecting the vertical structure of the early medieval Turks society.

The archaeological materials and complementary written resources evidence a peculiar dynamics of the early medieval Turkic social system. The changes in this area were mostly associated with the political situation in the region. At various stages of its development, the nomadic social system was influenced by neighboring settled agriculturalists, primarily in China, with whom contacts were most intense. The complex organization of the early medieval nomadic society is also evidenced by the heterogeneous elites that included not only representatives of the military elite, but also managers not directly connected with military affairs.

The limitations of the available archaeological materials prevent a full implementation of all opportunities of social reconstructions. The prospects for further research are connected with a more thorough analysis of written sources and correlation of information contained therein with the results of the analysis of burial complexes (Seregin and Tishin 2017). Further research in this direction will contribute to the understanding of complex processes of formation and evolution of the early medieval Turks' social system, as well as an objective assessment of the degree to which it was affected by diverse factors.

\section{NOTES}

* This study has been supported by the mega-grant of the Government of Russian Federation (№ 14.W03.31.0016) ‘Dynamics of peoples and empires in Inner Asia.' 


\section{REFERENCES}

Alekseev, V. P., and Debets, G. F. 1964. Craniometry. Methods of Anthropological Research. Moscow: Nauka. Original in Russian (Алексеев, В. П., Дебец, Г. Ф. Краниометрия. Методика антропологических исследований. М.: Наука).

Balabanova, M. A. 2009. Gender and Age Population Structure of the Late Sarmatian Period of the Lower Volga Region. Rossiyskaya Arkheologhia 3: 77-89. Original in Russian (Балабанова, М. А. Половозрастная структура населения позднесарматского времени Нижнего Поволжья. Российская археология 3: 77-89).

Bernshtam, A. N. 1946. Socioeconomic Structure of the Orkhon-Yenisei Turks of the $7^{\text {th }}$ - ${ }^{\text {th }}$ Centuries AD. Moscow - Leningrad: Izd-vo AN SSSR. Original in Russian (Бернштам, А. Н. Социально-экономический строй орхоно-енисейских тюрок VI-VIII веков. М. - Л.: Изд-во АН СССР).

Berseneva, N. A. 2010a. Gender Analysis of Children's Burials: Theoretical Approaches, Problems and Prospects. In Chernaya, M. P. (ed.), Culture as a System in a Historical Context (pp. 107-110). Tomsk: Agraf-Press. Original in Russian (Берсенева, Н. А. Гендерный анализ детских погребений в древних обществах: теоретические подходы, проблемы и перспективы. В: Черная, М. П. (ред.), Культура как система в историческом контексте (с. 107-110). Томск: Аграф-Пресс)

Berseneva, N. A. 2010b. Burial Monuments of the Sargat Culture of the Middle Irtysh Region: A Gender Analysis. Arkheologiya, Etnografiya $i$ antroplogiya Evrazii 3 (43): 72-81. Original in Russian (Берсенева, Н. А. Погребальные памятники саргатской культуры Среднего Прииртышья: гендерный анализ. Археология, этнография и антропология Евразии 3 (43): 72-81).

Berseneva, N. A. 2011. Social Archaeology: Age, Gender, and Status in Burials of the Sargat Culture. Ekaterinburg: UrO RAN. Original in Russian (Берсенева, Н. А. Социальная археология: возраст, гендер и статус в погребениях саргатской культуры. Екатеринбург: УрО РАН).

Bichurin, N. Ya. 1950. A Collection of Data on Peoples Living in Central Asia in the Ancient Times. Vol. 1. Moscow - Leningrad: Izd-vo AN SSSR. Original in Russian (Бичурин, Н. Я. Собрание сведений о народах, обитавщих в Средней Азии в древние времена. Т. 1. М. - Л.: Изд-во АН СССР).

Gavrilova, A. A. 1965. The Kudyrge Mound as a Source on the History of the Altaic Tribes. Moscow - Leningrad: Nauka. Original in Russian (Гаврилова, А. А. Могильник Кудыргэ как источник по истории алтайских племен. М. - Л.: Наука).

Gryaznov, M. P. and Khudyakov, Yu. S. 1979. The Kyrghyz Time. In Gryaznov, M. P. (ed.), The Archaeological Monuments Complex near the Tepsey Mountain on the Yenisei (pp. 146-159). Novosibirsk: Nauka. Original in Russian (Грязнов, М. П., Худяков, Ю. С. Кыргызское время. В: Грязнов, М. П. (ред.) Комплекс археологических памятников у горы Тепсей на Енисее (с. 146159). Новосибирск: Наука).

Evtyukhova, L. A., and Kiselev, S. V. 1941. A Report on the Works of the SayanAltai Archaeological Expedition in 1935. Trudy Gosudarstvennogo istoricheskogo muzeya 16: 75-117. Original in Russian (Евтюхова, Л. А., Кисе- 
лев, С. В. Отчет о работах Саяно-Алтайской археологической экспедиции в 1935 г. Труды Государственного исторического музея 16: 75-117).

Klyashtorny, S. G., and Savinov, D. G. 2005. The Steppe Empires of Ancient Eurasia. Saint Petersburg: Philology Department SPbGU. Original in Russian (Кляшторный, С. Г., Савинов, Д. Г. Степные империи древней Евразии. СПб: Филологический факультет СПбГУ).

Kradin, N. N., Danilov, S. V., and Konovalov, P. B. 2004. Social Structure of the Transbaikalian Xiongnu. Vladivostok: Dalnauka. Original in Russian (Крадин, Н. Н., Данилов, С. В., Коновалов, П. Б. Социальная структура хунну Забайкалья. Владивосток: Дальнаука).

Kubarev, G. V. 2005. Culture of the Ancient Altaic Turks (Based on the Materials of Burial Monuments). Novosibirsk: Izd-vo IAET SO RAN. Original in Russian (Кубарев, Г. В. Культура древних тюрок Алтая (по материалам погребальных памятников). Новосибирск: Изд-во ИАЭТ СО РАН).

Kychanov, E. I. 1997. Nomadic States from the Xiongnu to the Manchus. Moscow: Vostochnaya literatura. Original in Russian (Кычанов, Е. И. Кочевые государства от гуннов до маньчжсров. М.: Восточная литература).

Liu, Mau-tsai. 2002. Information on Ancient Turks in the Medieval Chinese Sources. Moscow: Izd-vo In-ta vostokovedeniya RAN. Original in Russian (Лю, Маоцай. Сведения о древних тюрках в средневековых китайских источни$\kappa a x$. М.: Изд-во Ин-та востоковедения РАН).

Malov, S. E. 1959. Ancient Turks Written Monuments of Mongolia and Kirgizia. Moscow - Leningrad: Izd-vo AN SSSR. Original in Russian (Малов, C. E. Памятники древнетюркской письменности Монголии и Киргизии. М. - Л.: Изд-во АН СССР).

Mogilnikov, V. A. 1990. The Ancient Turks Barrows Kara-Koba-I. In Surazakov, A. S. (ed.), Problems of the Study of Ancient and Medieval History of Gorny Altai (pp. 137-185). Gorno-Altaysk: GANEEIYaL. Original in Russian (Могильников, В. А. Древнетюркские курганы Кара-Коба-I. В: Суразаков, А. С. (ред.), Проблемы изучения древней и средневековой истории Горного Алтая (с. 137-185). Горно-Алтайск: ГАНИИИЯЛ).

Mogilnikov, V. A. 1997. The 85 Kara-Koby-I Barrow and Some Results of the Study of Ancient Turks Monuments. In Surazakov, A. S. (ed.), Sources on the Study of History of the Republic of Altai (pp. 187-234). Gorno-Altaysk: GAIGI. Original in Russian (Могильников, В. А. Курган 85 Кара-Кобы-І и некоторые итоги изучения древнетюркских памятников Алтая в связи с исследованиями в Кара-Кобе. В: Суразаков, А. С. (ред.), Источники по истории Республики Алтай (с. 187-234). Горно-Алтайск: ГАИГИ).

Nesterov, S. P., and Khudyakov, Yu. S. 1979. The Burial with the Horse of the Burial Mound Tepsey-III. In Aseev, I. V. (ed.), Siberia in the Antiquity (pp. 88-92). Novosibirsk: Nauka. Original in Russian (Нестеров, С. П., Худяков, Ю. С. Погребение с конем могильника Тепсей-ІІІ. В: Асеев, И. В. (ред.), Сибирь в древности (с. 88-92). Новосибирск: Наука).

Poselyanin, A. I., Kirginekov, E. N., and Tarakanov, V. V. 1999. The Study of the Burial Mound Belyy Yar-II. In Khudiakov, Yu. S. (ed.), Eurasia: the Cultural Heritage of Ancient Civilizations (pp. 88-116). Issue. 2. Novosibirsk: NGU 
Publ. Original in Russian (Поселянин, А. И., Киргинеков, Э. Н., Тараканов, В. В. Исследование средневекового могильника Белый Яр-II. В: Худяков, Ю. С. (ред.), Евразия: культурное наследие древних ииивилзаций (c. 88-116). Вып. 2. Новосибирск: НГУ).

Ryabova, T. B. 2003. Stereotypes and Stereotypization as a Problem of Gender Studies. Personality. Culture. Obschetstvo 1-2 (15-16): 120-138. Original in Russian (Рябова, Т. Б. Стереотипы и стереотипизация как проблема гендерных исследований. Личность. Культура. Общество 1-2 (15-16): 120138).

Savinov, D. G. 1994. Cemetery Bertek-34. In Molodin, V. I. (ed.), Ancient Cultures of the Bertek Valley (pp. 104-124). Novosibirsk: Nauka. Original in Russian (Савинов, Д. Г. Могильник Бертек-34. В: Молодин, В. И. (ред.) Древние культуры Бертекской долины (с. 104-124). Новосибирск: Наука).

Seregin, N. N. 2012. Common and Specific Characteristics of Women's Burials of the Early Medieval Turks of Central Asia (Toward the Reconstruction of Some Aspects of Gender History. Vestnik arkheologii, antropologii i etnografii 2 (17): 61-69. Original in Russian (Серегин, Н. Н. Общие и особенные характеристики женских погребений раннесредневековых тюрок Центральной Азии (к реконструкции некоторых аспектов гендерной истории). Вестник археологии, антропологии и этнографии 2 (17): 61-69).

Seregin, N. N. 2013a. Social Organization of the Early Medieval Turks of the AltaiSayan Region and Central Asia (Based on the Materials of Burial Complexes. Barnaul: Altai University press. Original in Russian (Серегин, Н. Н. Социальная организаиия раннесредневековых тюрок Алтае-Саянского региона и Центральной Азии (по материалам погребальных комплексов). Барнаул: Изд-во Алт. ун-та).

Seregin, N. N. 2013b. Elite of the Early Medieval Turks of the Sayan-Altai (Based on Materials of Burial Complexes. Short Proceedings of the Institute of Archaeology 229: 71-83. Original in Russian (Серегин, Н. Н. Элита раннесредневековых тюрок Саяно-Алтая (по материалам погребальных комплексов). Краткие сообщения Института археологии 229: 71-83).

Tishin, V. V. 2014. To the Problem of Exploitation Forms and Social Dependence in the Ancient Turks Milieu of the $6^{\text {th }}-11^{\text {th }}$ Centuries: A Historiographical Aspect. Etnograficheskoye obozreniye 4: 93-107. Original in Russian (Тишин, В. В. К проблеме форм эксплуатации и социальной зависимости в древнетюркской среде VI-XI вв.: историографический аспект. Этнографическое обозрение 4: 93-107).

Tishkin, A. A., and Dashkovskiy, P. K. 2003. Social Structure and Worldview System of the Altaic Population in the Scythian Epoch. Barnaul: Altai University press. Original in Russian (Тишкин, А. А., Дашковский, П. К. Социальная структура и система мировоззрений населения Алтая скифской эпохи. Барнаул: Изд-во Алт. ун-та).

Tugusheva, L. Yu. 2008. Turks Runic Monuments from Mongolia. Moscow: INSAN Publ. Original in Russian (Тугушева, Л. Ю. Тюркские рунические памятники из Монголии. М.: ИНСАН). 